\title{
The Effect of Soil Density on Infiltration Rate in The Urban Development Area of Padang
}

\author{
Totoh Andayono ${ }^{1, \text { a) }}$ \\ ${ }^{1}$ Civil Engineering Department, Engineering Faculty, Universitas Negeri Padang \\ a) to.handayono@gmail.com
}

\begin{abstract}
Most of the population in Padang live in the region along the seashore, public facility and economic center with all its supporting facilities. Padang city has a high potential for earthquake and tsunami including puddles of a flood. This condition encourages the local government to develop urban areas towards the North, East, and South (Koto Tangah, Kuranji, Pauh, Lubuk Kilangan and Bungus Teluk Kabung sub-districts), where it was previously a rainwater catchment area. The land was changed by using which create the density of the soil and infiltration of rainwater to be changed into the soil. This research was conducted at 15 locations in Dadok Tunggul Hitam area, Koto Tangah sub-district (9 locations in the development area and 6 locations in original area condition). Double Ring Infiltrometer is used in this study to predict infiltration rate and Sandcone for measuring soil density. This study used Horton Model to analyze infiltration rate by quantifying infiltration rate data (f), constant infiltration rate $\left(\mathrm{f}_{\mathrm{c}}\right.$ ) and initial infiltration rate $\left(\mathrm{f}_{\mathrm{o}}\right)$. Moreover, regression analysis was used to quantify infiltration rate to determine its effects on soil density parameter $\mathrm{s}$. The results show that for high density soil (value $\gamma_{\mathrm{d}}=1.00 \mathrm{gr} / \mathrm{cm}^{3}$ to $1.50 \mathrm{gr} / \mathrm{cm}^{3}$ ), final soil infiltration rate in average is $0.1 \mathrm{~mm} / \mathrm{min}$ to $0.9 \mathrm{~mm} / \mathrm{min}$. This condition can cause decreasing of rainfall`s runoff infiltration capacity. Meanwhile, for low density of soil (value $\gamma_{\mathrm{d}}=0.30 \mathrm{gr} / \mathrm{cm}^{3}$ to $1.00 \mathrm{gr} / \mathrm{cm}^{3}$ ), the infiltration rate value relatively high with final infiltration rate reached $0,22 \mathrm{~mm} / \mathrm{min}$. This analysis demonstrated that soil density influence the infiltration rate, where $23.7 \%$ of infiltration capacity in Padang City development area is influenced by soil density parameter $\left(\gamma_{\mathrm{d}}\right)$, and the rest is influenced by other parameters.
\end{abstract}

Keywords : infiltration rate, soil density, horton model

\section{INTRODUCTION}

Most of the population in Padang live in the lowland areas (30\% of the total geographical area) used as settlement, centers of economic activity, and public buildings. This densely populated and economic center of the region stretches along the coast, an area prone to earthquakes, the potential for tsunamis and flooding.

In response, the Regional Planning Board (BAPEDA) of Padang City plans to develop the city year 20082018, "Encouraging the development of urban settlement areas towards the North, East, and South (Koto Tangah, Kuranji, Pauh, Lubuk Kilangan and Bungus Teluk Kabung). Infrastructure and facilities have been built in the area cause the community to build housing to the development area of the city, and the surrounding area, one of them is Dadok Tunggul Hitam (Koto Tangah sub-district).

Dadok Tunggul Hitam used to be a rainwater catchment area, the impact of development activities in the area changed the conversion of land into residential areas.The land use change is considered to have disrupted the chain of hydrological cycles caused by changing soil conditions such as soil density, soil porosity, soil density and others. The impact is if there is rain with high-intensity water puddles are often quite high because of most of the rainwater into the flow of the surface and a small part into infiltration. Soil density is the most significant parameter of change in Tunggul Hitam, as hoarding and compacting has been done. Therefore, it is necessary to do research to know how much influence of soil density to infiltration rate in the urban development area and to get contribution of influence of soil density parameter.

Infiltration is the entry of water from the soil surface into the soil. The magnitude of infiltration is affected by the intensity of the rain, the slope of the soil surface, the land cover condition (vegetation), soil moisture and soil permeability, i.e. soil absorption. The soil permeability is affected by soil texture, soil density, soil structure, porosity and rooting system of plants. 
The capacity of infiltration is the ability of the soil to permeate the water [1]. The infiltration capacity can be described using the infiltration capacity curve and using the rainfall intensity diagram. The Horton model is one of the famous infiltration models in hydrology. According to Horton, the infiltration capacity decreases with increasing time to close to constant value. The equation of the infiltration capacity curve according to Horton is:

$$
\begin{array}{ll}
f= & f_{c}+\left(f_{0}-f_{c}\right) \cdot e^{-K . t} \\
\mathrm{f} & =\text { infiltration capacity }(\mathrm{cm} / \mathrm{h}) \\
\mathrm{f}_{0} & =\text { initial infiltration capacity } \\
\mathrm{f}_{\mathrm{c}} & =\text { constant infiltration capacity } \\
\mathrm{K} & =\text { constant } \\
\mathrm{t} & =\text { time calculated from the beginning of the rain }
\end{array}
$$

Infiltration rate measurements used double ring infiltrometer, one cylinder infiltrometer placed inside another larger cylinder infiltrometer. Measurements were only conducted on small cylinders. Larger cylinders served only as a buffer that reduced the boundary effect that cylinders [2].

Measurement of soil density using sandcone was intended to determine the field density of the soil layer or the compacted soil pavement by measuring the volume of the hole directly, measured by determining the dry unit weight $\left(\gamma_{\mathrm{d}}\right)$, the greater the dry unit weight means, the smaller the void ratio (e).

\section{RESEARCH METHOD}

The research location is Dadok Tunggul Hitam, one of the development areas of Padang city, as many as 15 testing points:

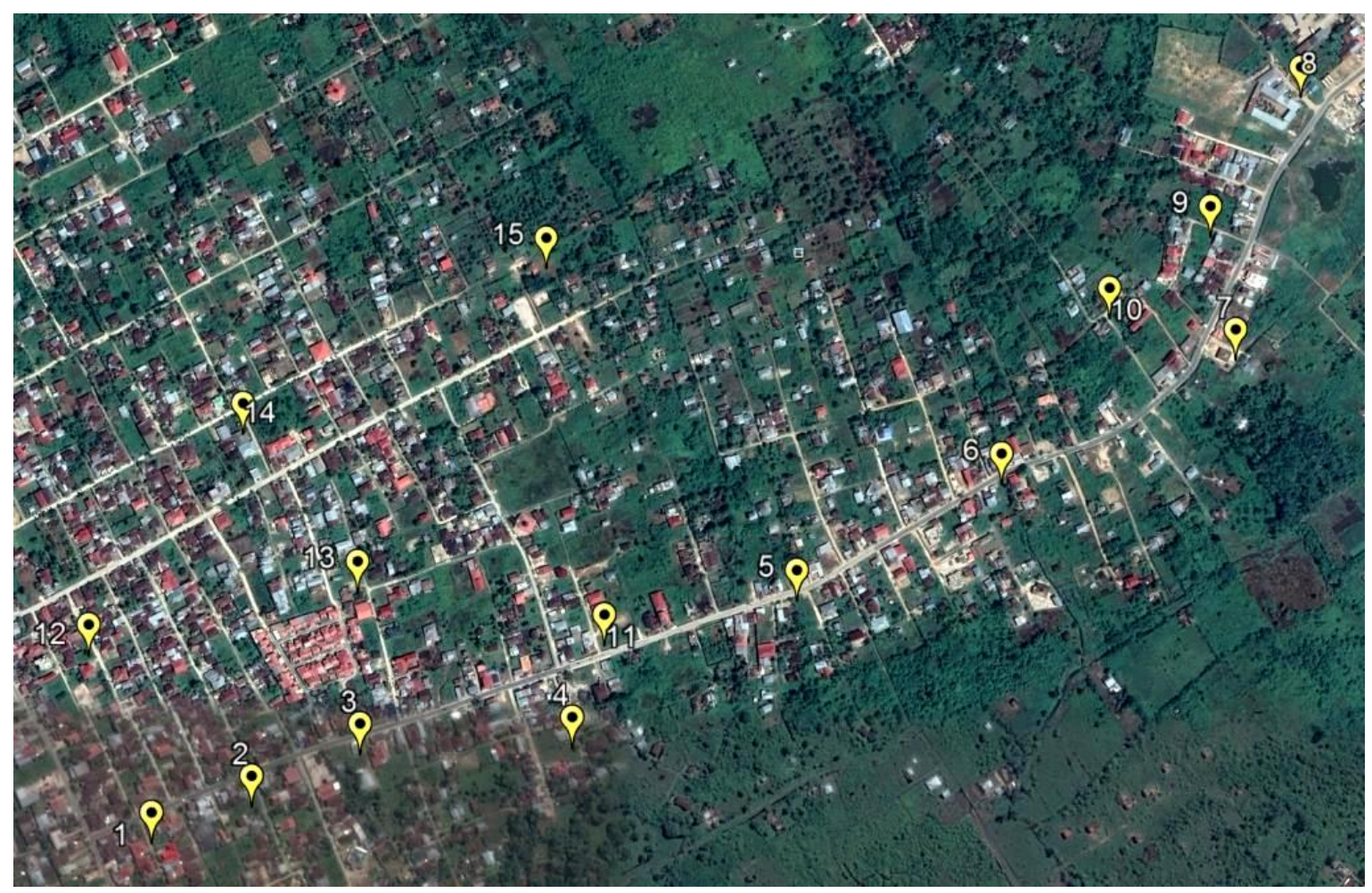

FIGURE 1. Research location points

Source : Google Earth

Measurements referred to standard infiltration testing based on SNI 77522012 [3] and soil density test with sand cone referred to ASTM D-1556 [4]. Analysis of measurement data was conducted using Horton model and laboratory test was conducted to know the effect of soil density on infiltration rate using excel program. 


\section{THE RESULT AND DISCUSSION}

\section{Soil Density}

The result of analysis of soil density measurement with sandcone at 15 point location resulted in the value of soil density and groundwater level as presented in following table:

TABLE 1. Soil Density Measurement Results

\begin{tabular}{|c|c|c|c|c|}
\hline \multirow{2}{*}{ Point } & \multicolumn{2}{|c|}{ Coordinate } & \multirow{2}{*}{$\begin{array}{l}\text { Dry unit weight } \\
\left(\mathrm{gr} / \mathrm{cm}^{3}\right)\end{array}$} & \multirow{2}{*}{ Category } \\
\hline & $\mathbf{X}$ & $\mathbf{Y}$ & & \\
\hline 1 & $0^{\circ} 52^{\prime} 36.67 "$ & $100^{\circ} 22^{\prime} 1.35^{\prime \prime}$ & 1.28 & High \\
\hline 2 & $0^{\circ} 52^{\prime} 35.32^{\prime \prime}$ & $100^{\circ} 22^{\prime} 5.08^{\prime \prime}$ & 1.26 & High \\
\hline 3 & $0^{\circ} 52^{\prime} 33.36^{\prime \prime}$ & $100^{\circ} 22^{\prime} 9.14^{\prime \prime}$ & 1.50 & High \\
\hline 4 & $0^{\circ} 52^{\prime} 33.11^{\prime \prime}$ & $100^{\circ} 22^{\prime} 17.17^{\prime \prime}$ & 0.85 & Low \\
\hline 5 & $0^{\circ} 52^{\prime} 27.57^{\prime \prime}$ & $100^{\circ} 22^{\prime} 25.68^{\prime \prime}$ & 1.32 & High \\
\hline 6 & $0^{\circ} 52^{\prime 2} 23.13^{\prime \prime}$ & $100^{\circ} 22^{\prime} 33.50^{\prime \prime}$ & 1.42 & High \\
\hline 7 & $0^{\circ} 52^{\prime} 18.37 "$ & $100^{\circ} 22^{\prime} 42.48^{\prime \prime}$ & 0.93 & Low \\
\hline 8 & $0^{\circ} 52^{\prime} 80.23^{\prime \prime}$ & $100^{\circ} 22^{\prime} 45.12^{\prime \prime}$ & 1.21 & High \\
\hline 9 & $0^{\circ} 52^{\prime} 13.61 "$ & $100^{\circ} 22^{\prime} 41.60^{\prime \prime}$ & 1.09 & High \\
\hline 10 & $0^{\circ} 52^{\prime} 16.76^{\prime \prime}$ & $100^{\circ} 22^{\prime} 37.70^{\prime \prime}$ & 1.29 & High \\
\hline 11 & $0^{\circ} 52^{\prime} 29.25^{\prime \prime}$ & $100^{\circ} 22^{\prime} 18.38^{\prime \prime}$ & 0.82 & Low \\
\hline 12 & $0^{\circ} 52^{\prime 2} 29.62^{\prime \prime}$ & $100^{\circ} 21^{\prime} 58.86^{\prime \prime}$ & 1.33 & High \\
\hline 13 & $0^{\circ} 52^{\prime} 27.23^{\prime \prime}$ & $100^{\circ} 22^{\prime} 90.01 "$ & 0.86 & Low \\
\hline 14 & $0^{\circ} 52^{\prime} 21.21 "$ & $100^{\circ} 22^{\prime} 4.60^{\prime \prime}$ & 0.36 & Low \\
\hline 15 & $0^{\circ} 52^{\prime} 14.86^{\prime \prime}$ & $100^{\circ} 22^{\prime} 16.12^{\prime \prime}$ & 0.29 & Low \\
\hline
\end{tabular}

\section{Infiltration Rate}

The result of infiltration rate measurement of 15 research points was divided into two density variations based on low and high density based on dry unit weight $\left(\gamma_{d}\right)$. The land that has a high density (high dry unit weight) is the soil of embankment which has been used for residence. Infiltration rate analysis using Horton model resulted in the following curve:

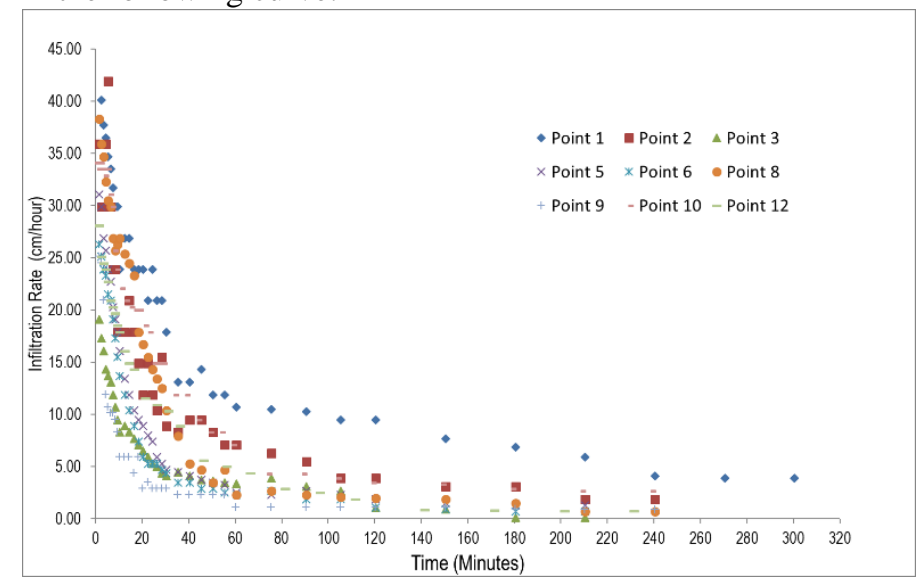

(a)

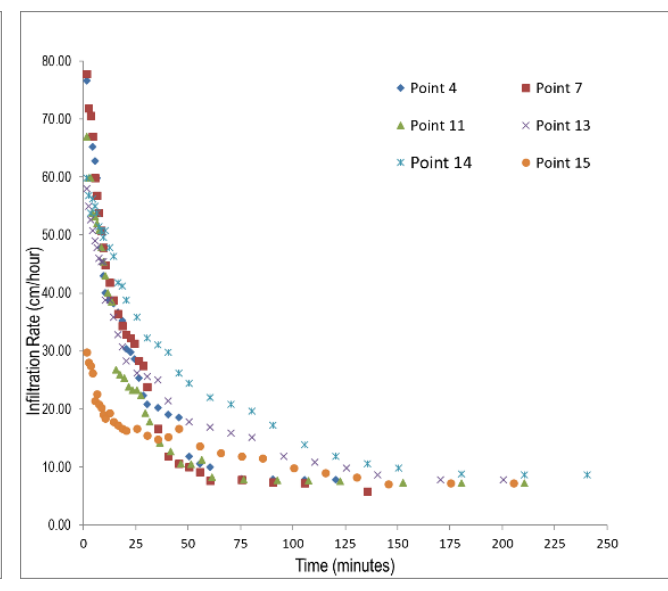

(b)

FIGURE 2. Graph of infiltration rate (a) high density (b) low density

The results of the measurements in Figure 1 show that in soil with high soil density the infiltration rate is low, while the soil with low density causes the infiltration rate to be high. 


\section{Horton Model Infiltration Rate}

The analysis of the infiltration rate of the Horton model that has been performed produced different curve shapes but yields curve trend form according to Horton model theory. The diversity of the curve is due to the many parameters affecting the infiltration rate such as the thickness of the surface layer of soil, water content, vegetation, texture and soil moisture. Based on two variations of soil density obtained by Horton model, the curve for average infiltration rate is shown below:

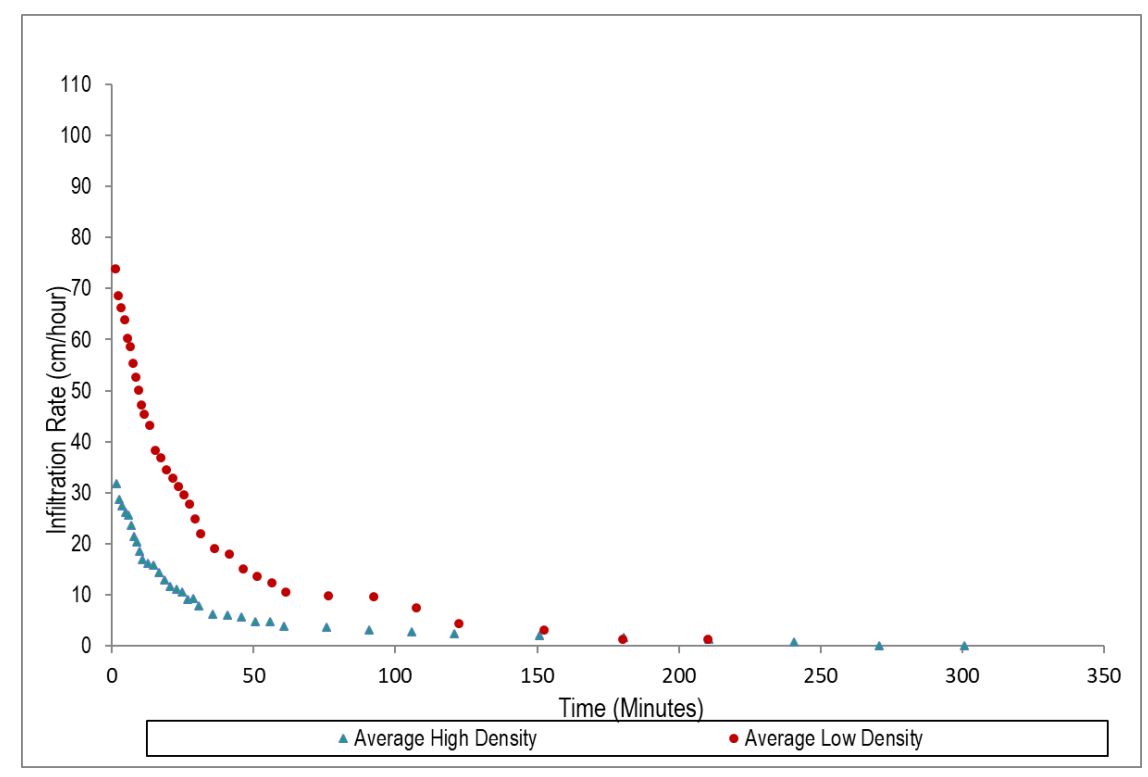

FIGURE 3. Average infiltration rate curve

In Figure 3, locations with high densities have low infiltration rate while for low-density soils have the high infiltration rate. This shows that the soil density affects the size of the infiltration, where the higher the density of a soil the smaller the soil void so that the seepage of water in the soil will be smaller. The result of statistical analysis ( $t$-test) proves that the density affects the infiltration rate, where $t$ stat $>t$ table.

At some point of measurement, high moisture conditions have the small infiltration rate (point 14 and point 15), although the density is low. This shows that infiltration rate is not only influenced by soil density but influenced by many other parameters.

\section{Effect of Soil Density on Infiltration Rate}

Based on the result of infiltration capacity value can be discussed the relationship of soil density with infiltration capacity. By using regression program excel obtained curve as follows:

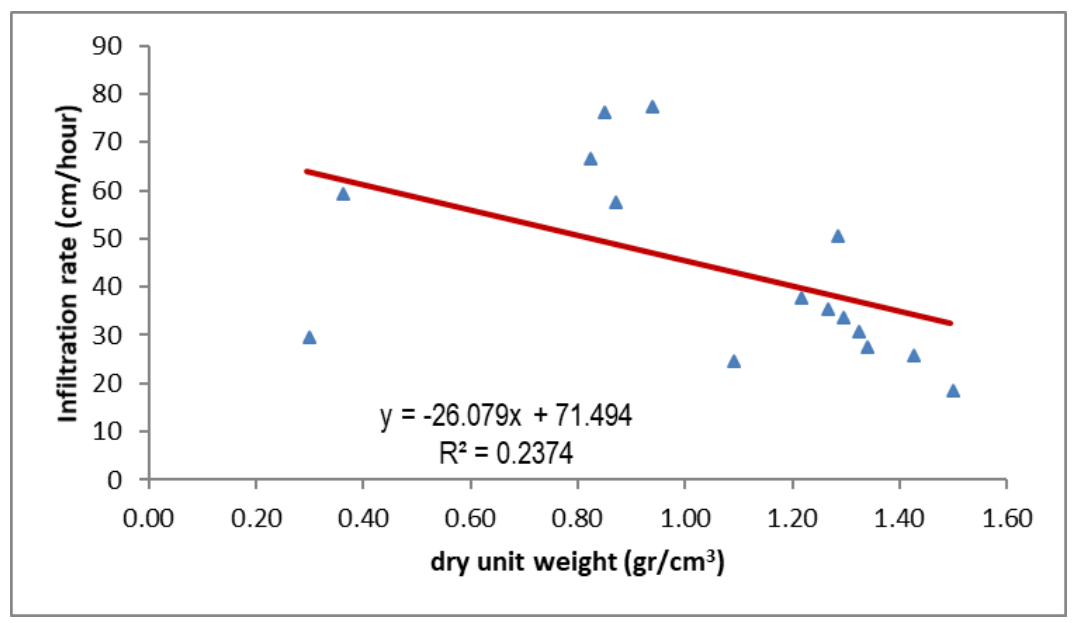

FIGURE 4. soil density relationship curve with infiltration rate 
By using exponential regression, the value of the coefficient of determination (R2) is 0.237 or $23.7 \%$, and it shows that the contribution of soil density parameter to infiltration rate at development location of the city of Padang is $23.7 \%$, the difference is influenced by other parameters.

The low coefficient of determination due to soil density is a non-dominant parameter affecting infiltration rate in Padang city development area; this is caused by many other factors influencing infiltration rates such as water content, compression by particle, vegetation, soil moisture, land slope, texture soil, water characteristics and soil structure. In addition, based on observations during field measurements, several points indicate that large soil densities provide a large infiltration rate after 90 minutes measurement or infiltration rate has exceeded $30 \mathrm{~cm}$ of soil depth-proving that the soil characteristics in the development area of Padang (Tunggul Hitam) permeability are high so as to provide a small coefficient of determination.

\section{SUMMARY}

Based on the results of t-test the relationship between soil density and infiltration rate in the development of Padang city has a significant relationship, but soil density is not a dominant parameter that affects the rate of infiltration. This is evidenced by the regression analysis showing the relationship between the density value with the infiltration rate maximum (infiltration capacity) has a value of $\mathrm{R}^{2}=0.237$ or soil density affects infiltration rate of $23.7 \%$, the difference is influenced by other parameters such as water content, compression by particles, vegetation, soil moisture, land slope, soil texture, and water characteristics and soil structure.

\section{REFERENCES}

[1] Kartasapoetra, Kerusakan Tanah Pertanian dan Usaha Untuk Merehabilitasinya. Jakarta: Bina Aksara, 1989.

[2] C. Asdak, Hidrologi dan Pengelolaan Daerah Aliran Sungai. Yogyakarta: Gadjah Mada University Press, 2002.

[3] SNI-7752:2012, Tata cara pengukuran laju infiltrasi tanah di lapangan menggunakan infiltrometer cincin ganda. Jakarta: BSN, 2012.

[4] ASTM-D1556, Standard Test Method for Density and Unit Weight of Soil in Place by Sand Cone Method. United States: American Standard Testing and Material. 